Jurnal Indonesia Sosial Teknologi: p-ISSN: 2723 - 6609

e-ISSN : 2745-5254

Vol. 2, No. 3 Maret 2021

\title{
PERANCANGAN SEQUENCE PENAMBANGAN BATUBARA DI PIT TUTUPAN SELATAN AREA MITSUBISHI, PT PAMAPERSADA NUSANTARA JOBSITE PT ADARO INDONESIA, KALIMANTAN SELATAN
}

\author{
Peter Mandew, Heru Juanda Putra, Ryan Habrianto dan Zico Hardianto \\ Teknik Pertambangan Universitas Jambi \\ Email: mandewpeter@gmail.com, herujuanda12@gmail.com, \\ ninghthabrianto@gmail.com, zkodir5@gmail.com.
}

\section{Abstract}

In mining activities, there is a mine plan to achieve the production target, a smaller mining design is made to facilitate control and maintain the production process in order to achieve the target with the mining sequence. The design of the mining sequence is a plan to create an overview of the stages of pit mining from the initial stage to the final stage of the mining limit (pit limit). PT Pamapersada Nusantara which is a contractor from PT Adaro Indonesia which has cooperation in the field of mining activities in the PKP $2 B$ PT Adaro Indonesia divides the coal mining sequence into several parts so that in this study it is planned to create a monthly mining sequence at the South Tutupan Pit based on the production schedule for April - June 2019. The research method used is descriptive quantitative method, namely research that produces data that is translated in the form of numbers for analysis. Based on the study results, the April sequence design has a 880,324 BCM overburden capacity and 183,949 tonnes of coal with SR 6.47; May's sequence design has a capacity of 962,032 BCM and coal 175,393 tonnes with SR 7.41; June's sequence design has a 641,562 BCM overburden capacity and 134,899 tonnes of coal with SR 6.43.

Keywords: Coal Mining, Mine Design, Mine Sequence.

\section{Abstrak}

Dalam kegiatan pertambangan terdapat perencanaan tambang untuk mencapai target produksi dibuat rancangan penambangan yang lebih kecil untuk mempermudah kontrol dan menjaga proses produksi agar dapat mencapai target dengan sequence penambangan. Perancangan sequence penambangan merupakan perencanaan untuk membuat gambaran dari tahapan - tahapan penambangan pit dari tahap awal hingga tahap akhir batas penambangan (pit limit). PT Pamapersada Nusantara yang merupakan kontraktor dari PT Adaro Indonesia yang memiliki kerjasama dalam bidang kegiatan penambangan pada PKP2B PT Adaro Indonesia membagi sequence penambangan batubara dalam beberapa bagian sehingga dalam penelitian ini direncanakan pembuatan sequence penambangan bulanan pada Pit Tutupan Selatan berdasarkan penjadwalan produksi bulan April - Juni 2019. Metode penelitian yang digunakan adalah metode kuantitatif deskriptif, yaitu penelitian yang menghasilkan data yang diterjemahkan dalam bentuk angka untuk dianalisis. Berdasarkan hasil penelitian, rancangan sequence bulan April memiliki 
kapasitas overburden 880.324 BCM dan batubara 183.949 ton dengan SR 6,47; rancangan sequence bulan Mei memiliki kapasitas overburden $962.032 \mathrm{BCM}$ dan batubara 175.393 ton dengan SR 7,41; rancangan sequence bulan Juni memiliki kapasitas overburden 641.562 BCM dan batubara 134.899 ton dengan SR 6,43.

Kata Kunci: penambangan batubara; perancangan tambang; sequence tambang.

\section{Pendahuluan}

Provinsi Kalimantan Selatan dikenal sebagai salah satu daerah yang mempunyai cadangan batubara. Berdasarkan data yang didapatkan dari Pusat Sumberdaya Geologi Tahun 2015 dalam laporan akhir Kajian Ketercapaian Target DMO Batubara Sebesar 60\% Produksi Nasional Pada Tahun 2019, cadangan batubara di Provinsi Kalimantan Selatan sebesar 3,6 miliar ton yang tersebar di setiap kabupaten di Provinsi Kalimantan Selatan. Salah satu perusahaan yang bergerak dibisnis penambangan batubara adalah PT Pamapersada Nusantara (PT. Nusantara, 2017). PT PAMA melakukan kegiatan penambangan pada area Pit Tutupan Selatan di dalam PKP2B PT Adaro Indonesia. Dikutip dari (Geost, 2016), Wilayah kuasa pertambangan PT Adaro Indonesia secara regional termasuk dalam Cekungan kutai. Secara khusus wilayah kerja penambangan PT Adaro Indonesia terletak pada Cekungan Barito yang terletak di tepi bagian timur Sub Cekungan Barito di dekat Pegunungan Meratus (Kajian, 2016).

Penambangan di Pit Tutupan Selatan dilakukan dengan sistem tambang terbuka. Menurut (Arteaga Munoz, 2014), tambang terbuka merupakan galian dangkal yang dikembangkan dengan tujuan untuk mengekstraksi bijih. Untuk menjalankan kegiatan penambangan batubara perlu dilakukan perencanaan yang baik sesuai dengan target produksi yang ingin dicapai. Suatu target produksi akan tercapai jika perencanaan tambang yang dilakukan sudah tepat.

Menurut (Purwaningsih, 2017), perencanaan tambang dibagi menjadi 3, yaitu perencanaan jangka panjang yang memuat perencanaan kegiatan untuk jangka waktu lebih dari 5 tahun secara berkesinambungan, perencanaan jangka menengah yang memuat suatu perencanaan kerja untuk jangka waktu antara 1-5 tahun, dan perencanaan jangka pendek yang memuat perencanaan aktivitas untuk jangka waktu kurang dari setahun demi kelancaran perencanaan jangka menengah dan panjang. Salah satu bentuk dari perencanaan tambang adalah membuat rancangan rancangan pit untuk jangka waktu tertentu.

Menurut (Prinandi, 2015), pada industri pertambangan rancangan tambang mencakup kegiatan - kegiatan seperti yang ada pada perencanaan tambang, tetapi semua data dan informasinya sudah rinci (pemodelan geologi, pit potensional, pit limit, geoteknik, stripping ratio, dan data pendukung lainnya). Rancangan pit ini akan memberikan gambaran mengenai batas penambangan (pit limit) untuk jangka waktu yang telah ditentukan. Parameter - parameter yang mempengaruhi batas penambangan (pit limit) untuk menghitung cadangan tertambang (mineable) dalam (Febrian, 2014) antara lain stripping ratio (SR), geometri lereng penambangan, dan kondisi topografi.

Menurut (Bargawa, 2018), Rancangan tahapan penambangan merupakan bentuk penambangan yang menunjukan bagaimana suatu tambang akan ditambang dari titik awal hingga bentuk akhir tambang. Pembuatan rancangan penambangan meliputi perancangan batas akhir penambangan, tahapan (sequence) penambangan, urutan penambangan tahunan/ bulanan, penjadwalan dan produksi dan waste dump (Wibowo, Usman, \& Maryanto, 2019). Tujuan dari pembuatan tahapan (sequence) penambangan 
yaitu untuk membagi seluruh volume yang ada dalam pit limit kedalam unit-unit perencanaan yang lebih kecil sehingga lebih mudah ditangani (Aryanda, Ramli, \& Djamaluddin, 2016).

Perancangan sequence penambangan dibuat berdasarkan jangka waktu tertentu dengan pertimbangan bentuk dan arah perlapisan endapan batubara, kapasitas alat yang digunakan, geometri lereng, jalan angkut (ramp), kondisi material dan stripping ratio yang diinginkan. Penentuan geometri lereng ada beberapa hal yang perlu dipertimbangkan yaitu sasaran produksi bulanan dan tahunan, ukuran alat mekanis yang digunakan, sesuai dengan ultimate pit slope, dan sesuai dengan kriteria slope stability. Bagian - bagian dari geometri lereng menurut (Hustrulid, Kuchta, \& Martin, 2013) adalah tinggi bench, lebar bench, working bench, dan kemiringan lereng.

Berdasarkan penelitian yang telah dilakukan di salah satu Pit yang ada di PT Adaro Indonesia yaitu di Pit Wara oleh PT Saptaindra Sejati (SIS) dari penelitian (Yusha, 2019), proses pembuatan rancangan sequence penambangan di lokasi kerja PT Adaro Indonesia dibuat pada setiap bulan dengan memperhatikan batas penambangan (pit limit) pada rancangan tahunan (yearly design). Pada proses penambangan yang telah berlangsung hingga saat ini PT PAMA telah mempunyai rancangan sequence Pit Tutupan Selatan hingga bulan Maret 2019. Namun, rancangan penambangan untuk target produksi bulan April - Juni 2019 belum dilakukan. Oleh karena itu, dalam penelitian ini penulis akan melakukan rancangan sequence penambangan batubara pada Pit Tutupan Selatan khusus di Area Mitsubishi untuk periode bulan April hingga Juni 2019.

\section{Metode Penelitian}

Jenis metode penelitian untuk tugas akhir ini adalah metode kuantitatif deskriptif, yaitu penelitian yang menghasilkan data yang diterjemahkan dalam bentuk angka untuk dianalisis. Penelitian tugas akhir ini termasuk dalam jenis penelitian terapan (Applied Research). Menurut (Gusmaningsih, Murad, \& Yulhendra, 2018), penelitian terapan adalah sebuah penelitian yang mencoba memberikan solusi yang lebih spesifik pada masalah-masalah kebijakan dan membantu para praktisi dalam menjalankan tugasnya.

Penelitian ini dilakukan pada Area Mitsubishi di Pit Tutupan Selatan Jobsite PT Adaro Indonesia, Kalimantan Selatan. Penelitian dilakukan selama 3 bulan yaitu pada tanggal 12 Maret 2019 sampai dengan 12 Juni 2019. Tahapan penelitian pertama yaitu pengumpulan data. Data-data yang digunakan dalam penelitian ini adalah sebagai berikut.

1. Peta lokasi perusahaan

Data ini digunakan sebagai informasi lokasi dari penelitian yang dilakukan.

2. Peta wilayah Izin Usaha Jasa Pertambangan (IUJP)

Data ini digunakan untuk mengetahui batasan luasan area tambang yang dikelola PT PAMA pada Jobsite PT Adaro Indonesia.

3. Data proyek topografi wilayah penambangan

Data proyek topografi merupakan data kontur digital yang menunjukkan kondisi daerah penelitian. Data proyek topografi bersumber dari data pemetaan yang telah diolah menjadi sebuah data proyek digital oleh pihak perusahaan. Data proyek topografi yang dimaksud adalah topografi situasi end of month (EOM) terbaru dan data persebaran batubara yang telah diolah berdasarkan situasi topografi dan informasi data bor perusahaan di lokasi penelitian. Data tersebut sudah diprogram 
sedemikian rupa sehingga pengguna dapat langsung melakukan perancangan pit dan perhitungan cadangan.

4. Data batas areal penambangan

Data batas areal penambangan digunakan untuk mengetahui batas penambangan (pit limit) pada rencana penambangan di Pit Tutupan Selatan tahun 2019. Data ini diperoleh dari desain tahunan (yearly design) untuk rencana penambangan di Pit Tutupan Selatan tahun 2019. Dari data ini dijadikan acuan sebagai batas dalam proses pembuatan rancangan sequence penambangan sehingga desain yang dihasilkan tetap berada dalam batas rancangan yang telah ditentukan.

5. Data rekomendasi geometri lereng penambangan

Data ini berisi informasi tinggi, lebar, dan kemiringan jenjang di Pit Tutupan Selatan. Pada proses pembuatan rancangan penambangan dalam penelitian ini, peneliti menggunakan rekomendasi geometri lereng dari perusahaan.

6. Data target produksi Bulan April - Juni 2019

Data ini berupa data target produksi overburden dan batubara di Area Mitsubishi Pit Tutupan Selatan untuk Bulan April - Juni tahun 2019. Selain itu dari data target produksi tersebut diperoleh juga nilai Stripping Ratio rancangan per bulan. Stripping ratio adalah perbandingan antara volume masa batuan yang dibongkar (lapisan tanah penutup) dengan batubara yang di ambil atau bisa juga disebut dengan besarnya volume tanah lapisan penutup yang harus dibongkar untuk mendapatkan 1 ton batubara (Ikhwal \& Murad, 2019).

7. Data spesifikasi alat mekanis

Spesifikasi alat mekanis ini berupa data spesifikasi alat muat dan angkut yang digunakan untuk menentukan lebar lereng kerja (working bench) dan lebar geometri jalan dari alat terbesar yang beroperasi di Area Mitsubishi. Data ini diperoleh dari handbook Komatsu.

Data-data yang telah didapatkan, selanjutnya dilakukan pengolahan data dengan batasan-batasan yang telah ditentukan untuk menghasilkan pemodelan geometri lereng, jalan angkut (ramp), dan rancangan tahapan penambangan (sequence) untuk bulan April - Juni 2019.

Dalam melakukan pengolahan data, metode yang digunakan adalah metode trial and error ketika membuat rancangan dan metode Inverse Distance Weighting (IDW) ketika menghitung cadangan dari rancangan yang telah dihasilkan dengan menggunakan perangkat lunak (software) tambang. Menurut Sasongko (2009), metode trial and error adalah metode dengan perlakuan simulasi dan iterasi (perulangan) untuk mendapatkan hasil rancangan yang sesuai dengan stripping ratio (SR) yang telah ditetapkan. Menurut (Amperadi, 2015) metode Inverse Distance Weighting (IDW) merupakan suatu cara penaksiran yang telah memperhitungkan adanya hubungan letak ruang (jarak). Metode ini mengkombinasikan model geologi dengan permukaan topografi yang terbentuk dalam bentuk solid surface/ triangle, kemudian dilanjutkan dengan menentukan batasan penambangan (pit limit) sebagai acuan perhitungan pada perangkat lunak tambang yang akan digunakan.

\section{Hasil dan Pembahasan \\ Kondisi Topografi Daerah Penelitian}

Topografi merupakan gambaran keadaan permukaan bumi yang digambarkan dengan garis kontur. Pada peta topografi dapat dilihat bentuk permukaan dan perbedaan elevasi suatu lokasi dari kerapatan serta nilai indeks kontur tersebut. Wilayah izin usaha 
Perancangan Sequence Penambangan Batubara di Pit Tutupan Selatan Area Mitsubishi, PT Pamapersada Nusantara Jobsite PT Adaro Indonesia, Kalimantan Selatan

jasa pertambangan PT PAMA di Jobsite PT Adaro Indonesia berada pada zona UTM 50S dengan koordinat $327822 \mathrm{mT}$ - $340322 \mathrm{mT}$ dan $9747775 \mathrm{mU}$ - $9760275 \mathrm{mU}$. Luas wilayah izin usaha jasa pertambangan (IUJP) PT PAMA di Jobsite PT Adaro Indonesia adalah seluas 13.340 Ha. Peta wilayah izin usaha jasa pertambangan (IUJP) PT PAMA Jobsite PT Adaro Indonesia dapat dilihat pada Gambar 1.

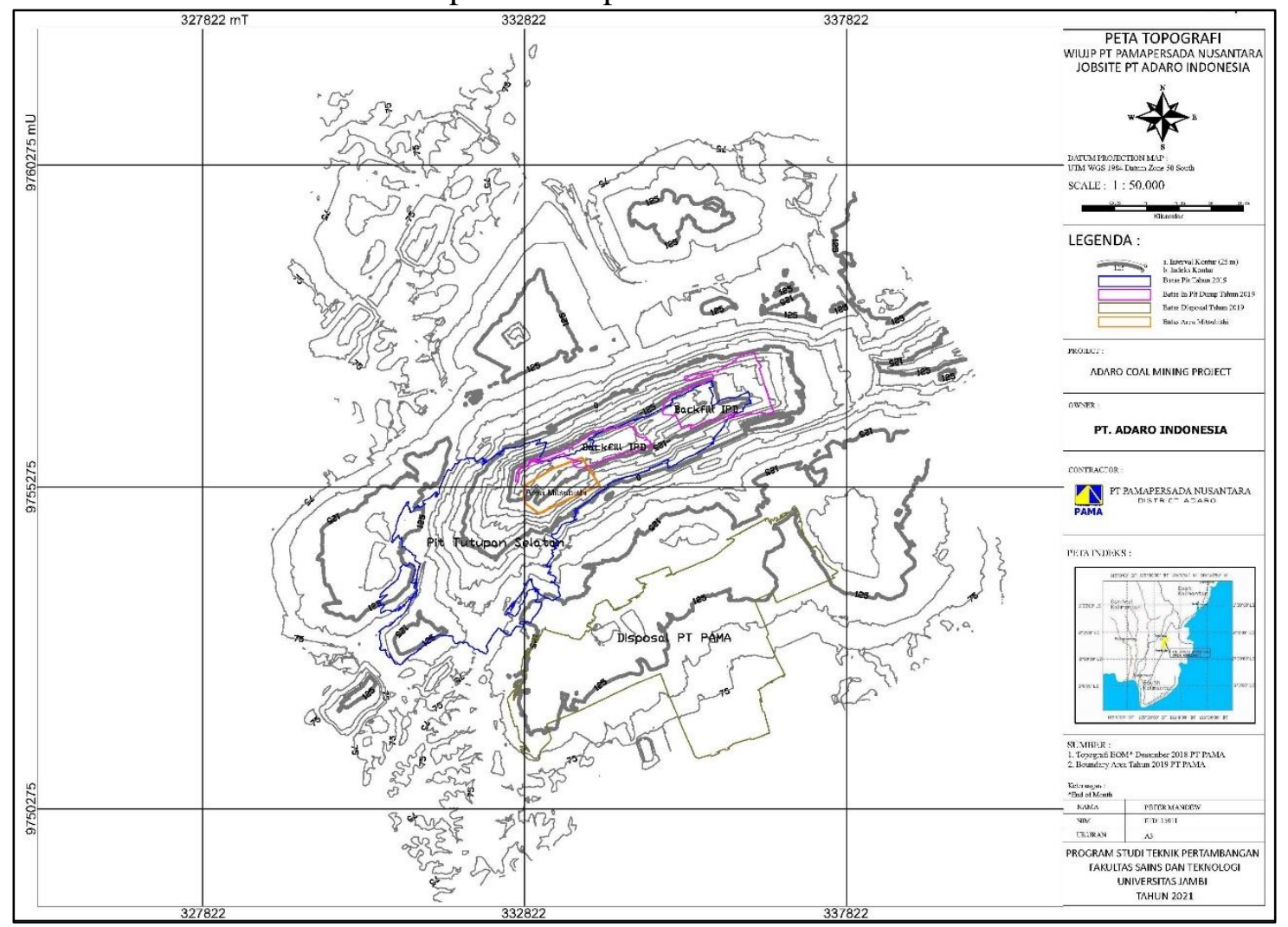

Gambar 1. Peta Wilayah Izin Usaha Jasa Pertambangan PT PAMA Jobsite PT Adaro Indonesia

\section{Batas Areal Penambangan}

Pada penelitian ini batas areal penambangan digunakan sebagai informasi batas pembuatan rancangan penambangan yang berhubungan dengan luas area bukaan pit yang telah ditentukan. Desain batas areal penambangan yang tersedia terdiri dari beberapa kategori, yaitu boundary pit, boundary disposal baik itu outpit dump serta inpit dump (area backfilling), dan boundary area Mitsubishi. Desain batas areal penambangan tersebut dapat dilihat pada Gambar 1.

\section{Kondisi Endapan Batubara}

Salah satu hal yang mempengaruhi dalam proses pembuatan rancangan penambangan adalah tempat penyebaran batubara serta gambaran bentuk batubara di bawah permukaan. Bentuk batubara di bawah permukaan dapat diketahui dengan membuat section line atau sayatan penampang. Section line adalah garis sayatan yang akan digambarkan dalam bentuk 2 dimensi. Sayatan penampang terdiri atas 6 garis yang berada pada daerah penelitian dengan interval jarak $200 \mathrm{~m}$ yang tegak lurus dengan strike dan searah dip yang dapat dilihat pada Gambar $\mathbf{2}$ dan hasilnya dapat dilihat pada Gambae 3. Hasil interpretasi dari kondisi endapan batubara di Area Mitsubishi dapat dilihat pada Tabel 1. 
Peter Mandew, Heru Juanda Putra, Ryan Habrianto, dan Zico Hardianto

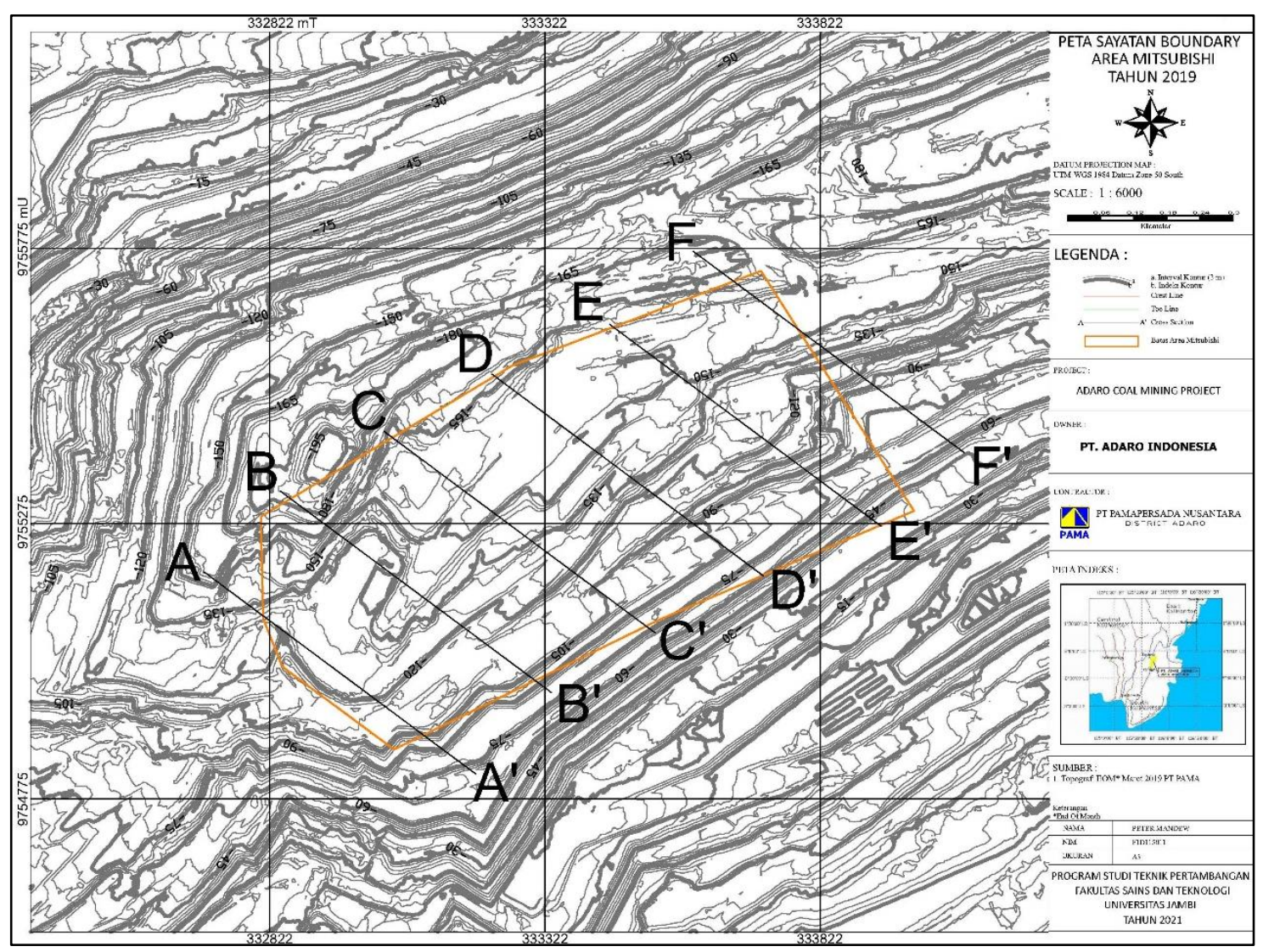

Gambar 2. Peta Sayatan Batas Areal Penambangan Area Mitsubishi Tahun 2019

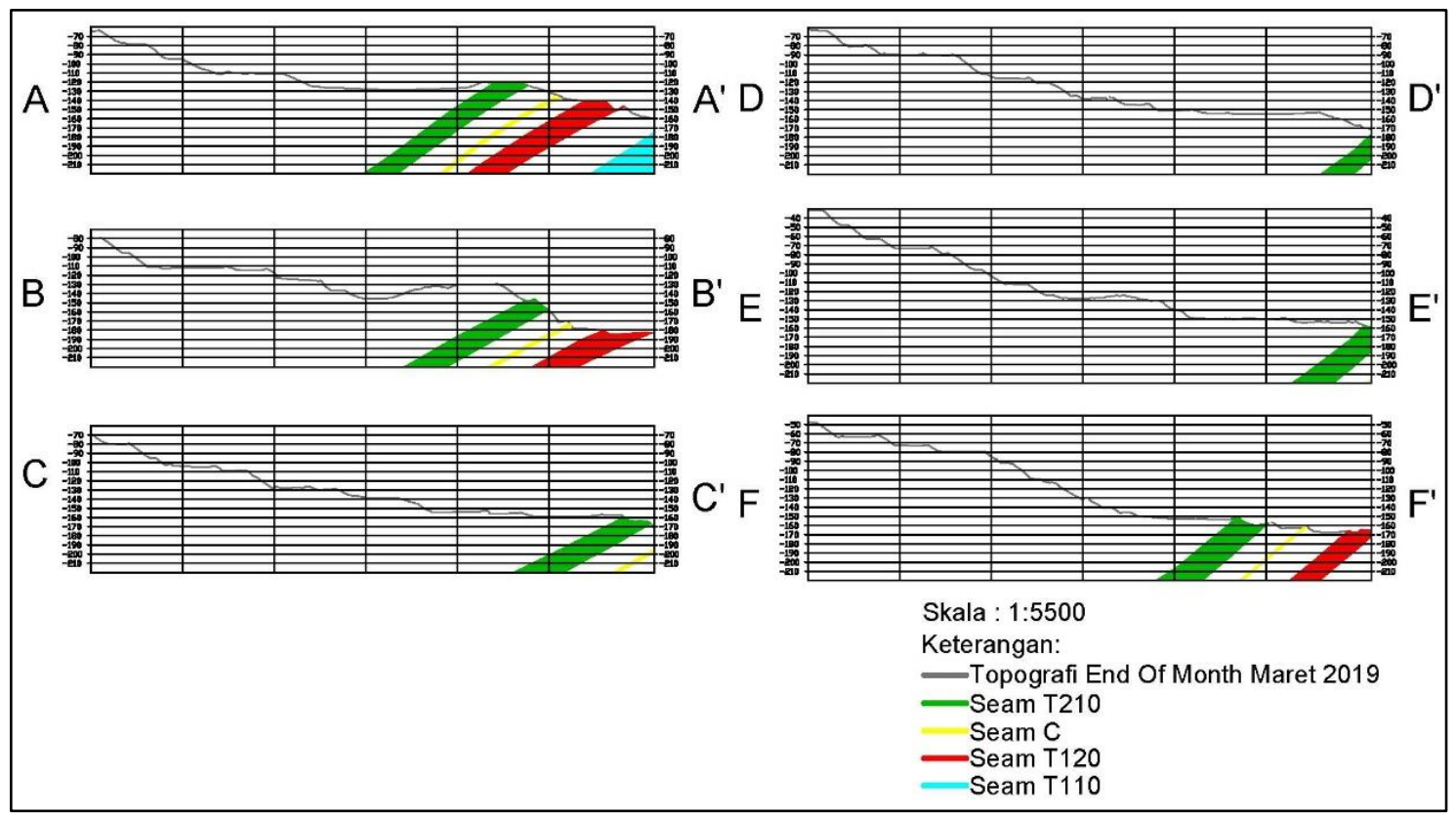

Gambar 3. Hasil Sayatan Batas Areal Penambangan Mitsubishi Tahun 2019 
Perancangan Sequence Penambangan Batubara di Pit Tutupan Selatan Area Mitsubishi, PT Pamapersada Nusantara Jobsite PT Adaro Indonesia, Kalimantan Selatan

Tabel 1 Ketebalan Lapisan Batubara

\begin{tabular}{ccc}
\hline Formasi & Seam & Coal Thickness $(\mathbf{m})$ \\
\hline \multirow{3}{*}{ Warukin } & T210 & 21 \\
& C & 3,5 \\
& T120 & 23,5 \\
& T110 & 36 \\
\hline
\end{tabular}

\section{Situasi Kerja di Area Mitsubishi}

Area Mitsubishi merupakan area penambangan yang berada pada bagian low wall timur di Pit Tutupan Selatan. Berdasarkan rancangan penambangan pada tahun 2019, Area Mitsubishi memiliki luas penambangan sebesar 56,34 Ha. Situasi kerja di Area Mitsubishi dapat dilihat pada Gambar 4.

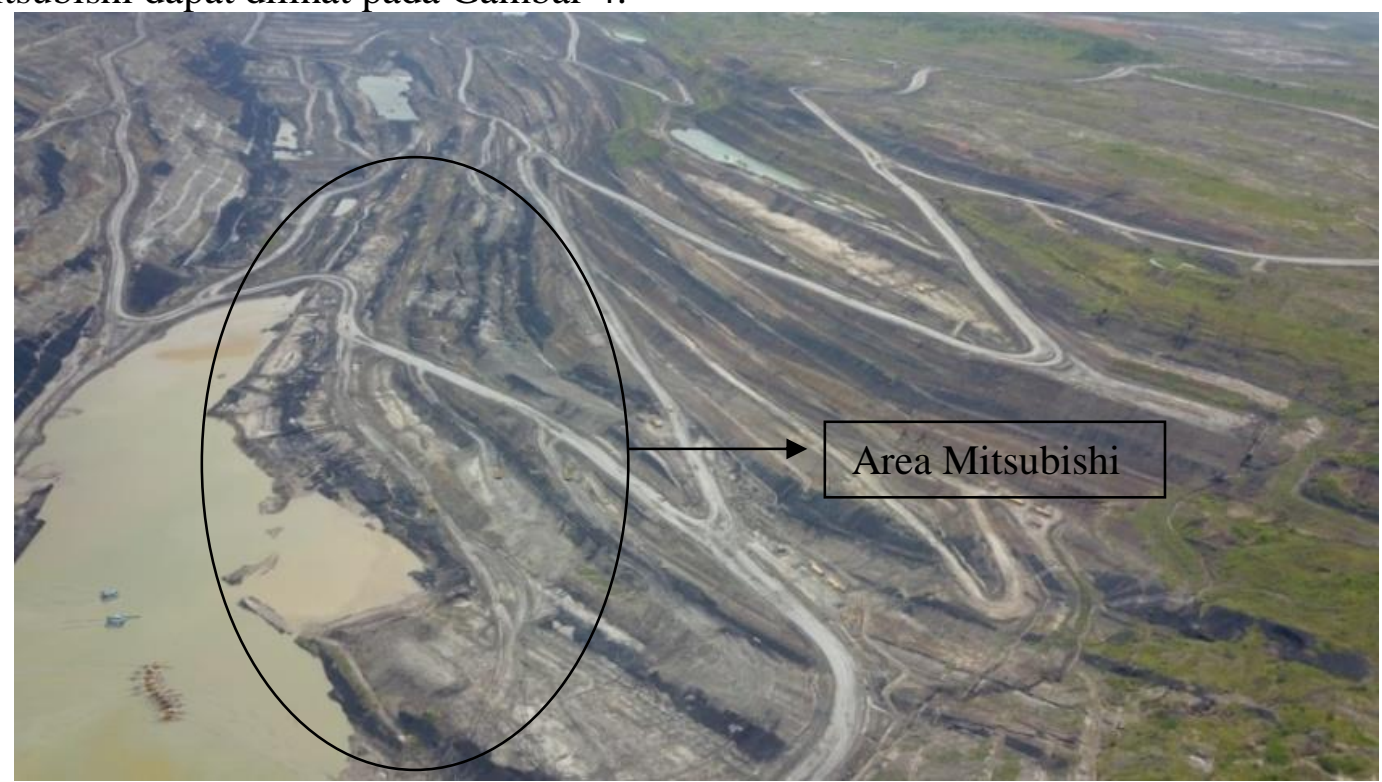

\section{Gambar 4. Situasi Kerja di Area Mitsubishi}

\section{Desain Geometri Lereng}

Geometri lereng akan mempengaruhi tingkat kestabilan lereng tambang. Pada penelitian ini desain lereng dibuat berdasarkan rekomendasi desain geometri lereng yang digunakan oleh perusahaan tempat penelitian dilaksanakan. Berdasarkan rekomendasi perusahaan maka desain geometri lereng di Area Mitsubishi adalah sebagai berikut:

- Single bench height $=16$ meter

- Bench width $\quad=10$ meter

- Single bench slope $=30^{\circ}$

- Overall bench slope $=25-30^{\circ}$

Bentuk desain geometri lereng dapat dilihat pada Gambar 5. 


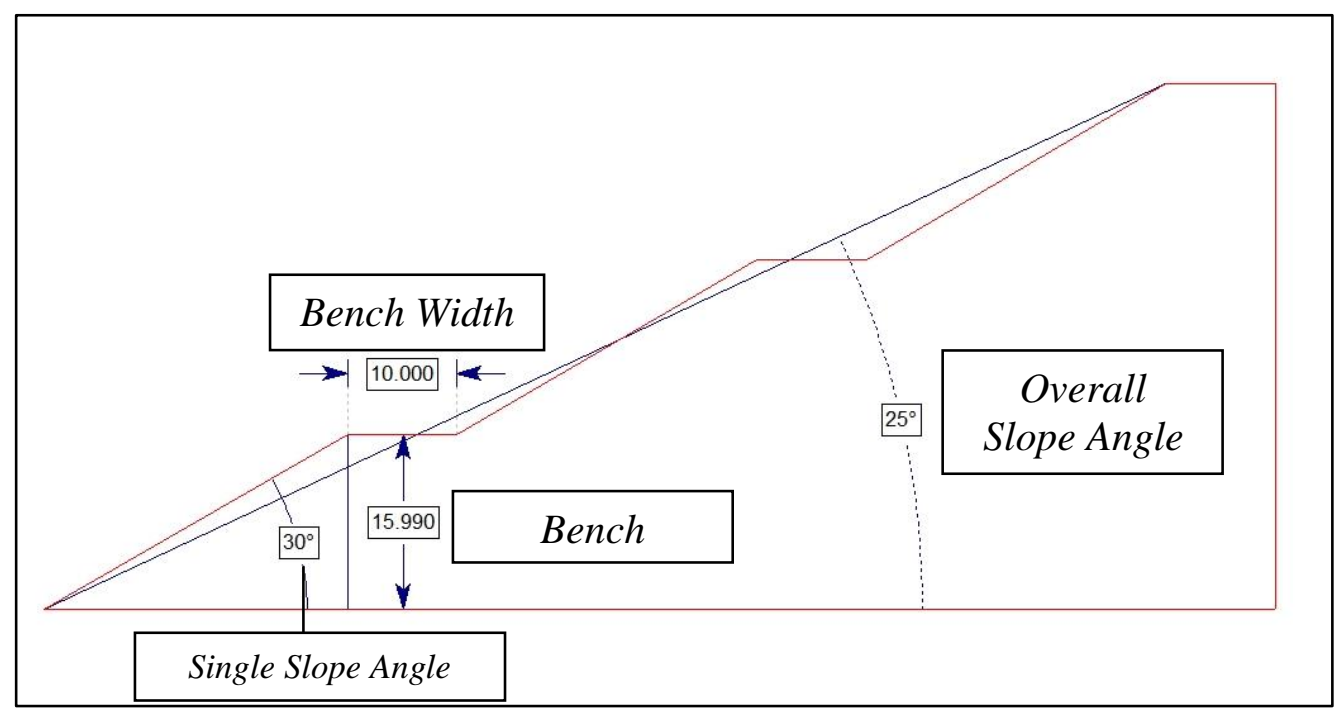

Gambar 5. Desain Geometri Lereng Area Mitsubishi

\section{Desain Pit Limit Pit Tutupan Selatan}

Desain pit limit merupakan desain yang memperlihatkan rencana kondisi akhir penambangan pada pit tersebut. Selain itu, desain pit limit juga digunakan untuk menunjukkan geometri bukaan secara keseluruhan guna menghitung cadangan batubara berdasarkan kondisi pemodelan lapisan batubara yang ada.

Penentuan pit limit sudah ditentukan pada pembuatan rencana penambangan selama satu tahun dengan output desain tahunan (yearly design). Oleh karena itu, rancangan penambangan setiap bulan yang akan dihasilkan tidak boleh melewati batas area tahunan yang telah ditetapkan. Rancangan final Pit Tutupan Selatan tahun 2019 dapat dilihat pada Gambar 6.

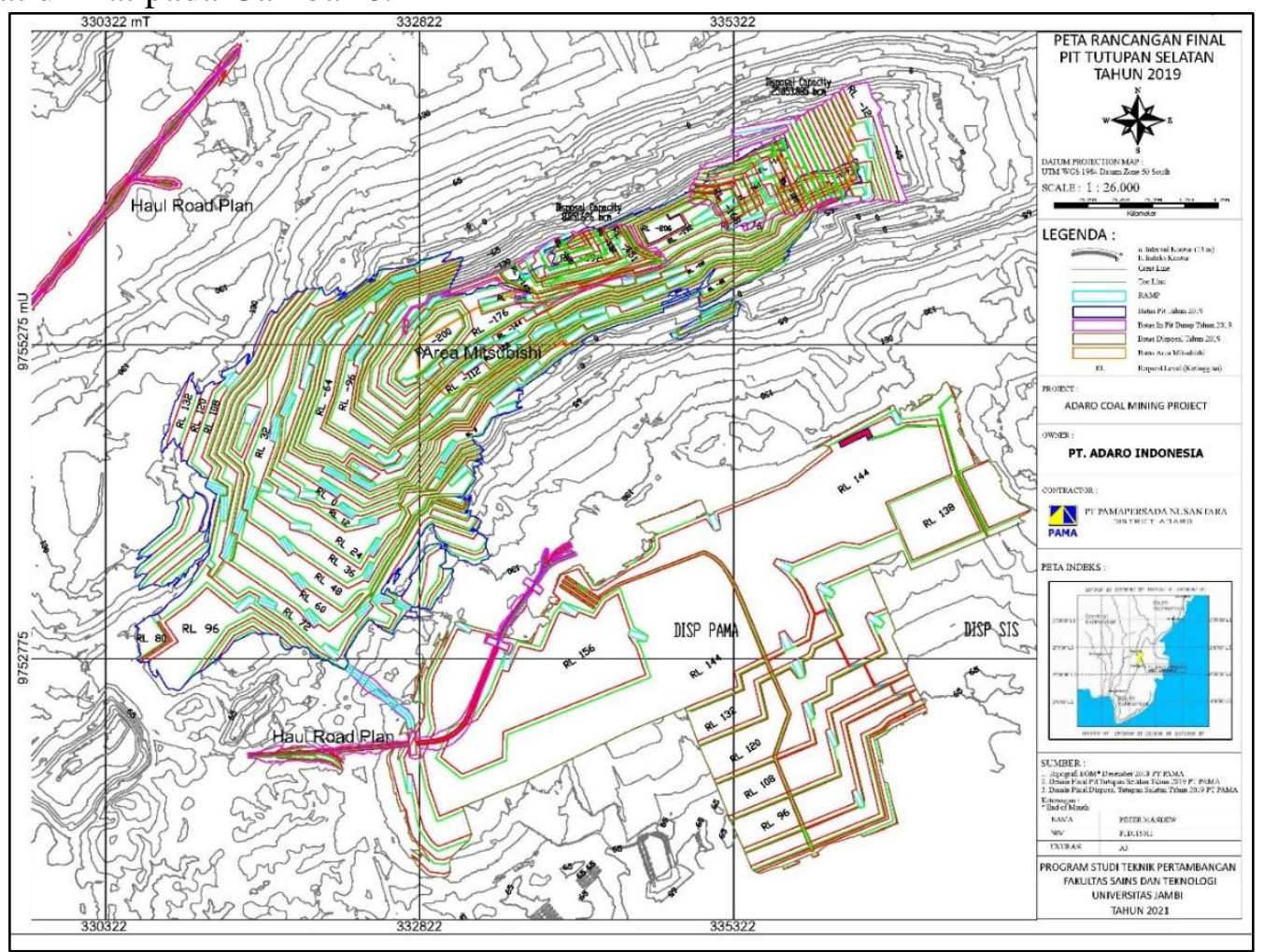

Gambar 6. Rancangan Final Pit Tutupan Selatan Tahun 2019 
Pada rancangan penambangan Pit Tutupan Selatan Tahun 2019, luas bukaan area pit penambangan adalah seluas 881,4 Ha dengan rencana elevasi tertinggi $132 \mathrm{mdpl}$ dan elevasi terendah -206 mdpl. Luas bukaan area disposal in pit dump pada area 1 seluas 52,3 Ha dan pada area 2 seluas 112,2 Ha dengan total luas kedua area seluas 164,5 $\mathrm{Ha}$ dengan rencana elevasi timbunan tertinggi hingga -120 mdpl pada area 1 dan -12 mdpl. Luas bukaan area disposal out pit dump adalah seluas 892,5 Ha dengan rencana elevasi timbunan tertinggi hingga 156 mdpl.

\section{Lebar Jenjang Kerja Minimum (Working Bench)}

Aturan lebar working bench menurut Kepmen ESDM No. 1827 K/30/MEM/2018 adalah area kerja penggalian memiliki luasan yang memadai untuk operasional peralatan yang digunakan paling kurang untuk 7 (tujuh) hari produksi. Standar minimum lebar working bench berdasarkan turning radius alat angkut komatsu yang beroperasi di Area Mitsubishi adalah 30 meter.

Aturan tinggi bench pada working bench menurut Kepmen ESDM No. 1827 K/30/MEM/2018 adalah tinggi dinding penggalian tidak boleh melebihi tinggi jangkauan efektif alat gali-muat terbesar yang dioperasikan. Alat gali-muat (excavator) terbesar yang dioperasikan di Area Mitsubishi adalah Komatsu PC2000. Berdasarkan spesifikasi alat Komatsu PC2000, maka tinggi penggalian maksimum (max. digging height) excavator Komatsu PC 2000 adalah 13.410 mm atau 13,4 meter.

\section{Geometri Jalan Angkut Tambang (Ramp)}

Menurut Kepmen ESDM No. 1827 K/30/MEM/2018, lebar jalan tambang/produksi mempertimbangkan alat angkut terbesar yang melintasi jalan tersebut paling kurang tiga setengah kali lebar alat angkut terbesar untuk jalan tambang dua arah dan dua kali lebar alat angkut terbesar untuk jalan tambang satu arah. Lebar jalan lurus di Area Mitsubishi menurut (PUTERA, Toha, \& Bochori, 2020) sebagai berikut:

$$
\begin{aligned}
\operatorname{Lmin}(2 \text { jalur }) & =3,5 \times \mathrm{Wt} \\
& =3,5 \times 5,53 \\
& =19,355 \mathrm{~m} \\
& =20 \text { meter }
\end{aligned}
$$

Keterangan:

$\mathrm{n} \quad=$ Jumlah jalur jalan angkut

$\mathrm{Wt}=$ Lebar alat angkut terbesar (meter)

Pada jalan angkut juga dibuat bahu jalan (shoulder) pada masing-masing tepi jalan sebelum safety berm dengan lebar 1,5 meter. Lebar jalan lurus secara keseluruhan adalah:

$$
\begin{aligned}
\mathrm{W} & =\text { Lebar jalan lurus }+ \text { lebar bahu jalan (shoulder) } \\
& =20 \mathrm{~m}+(1,5 \mathrm{~m} \times 2) \\
& =20 \mathrm{~m}+3 \mathrm{~m} \\
& =23 \text { meter }
\end{aligned}
$$

Secara keseluruhan diperoleh lebar jalan lurus minimum di Area Mitsubishi sebesar 23 meter. Bentuk desain jalan lurus tersebut dapat dilihat pada Gambar 7. 


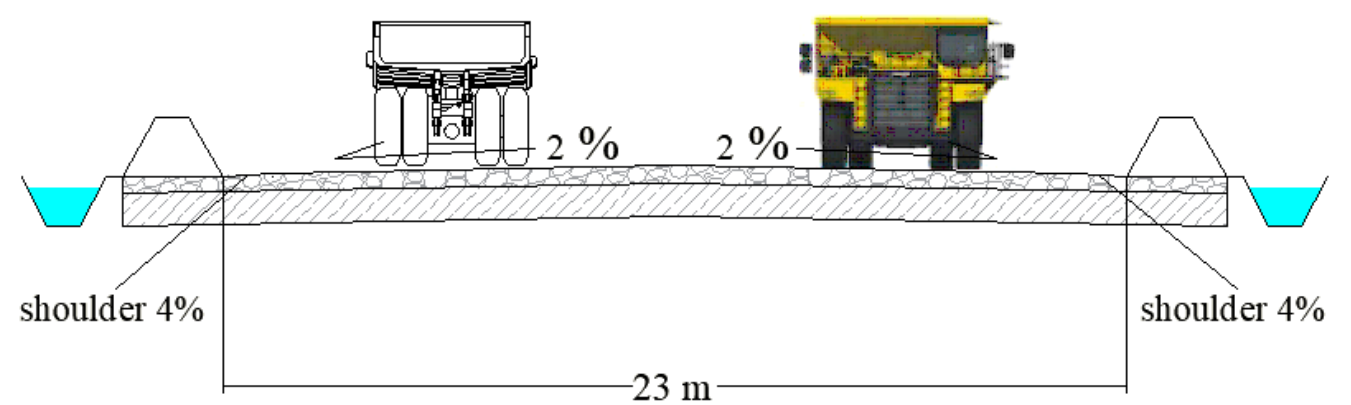

Gambar 7. Desain Jalan Lurus Jalan Angkut Tambang

Kemiringan jalan atau grade merupakan faktor penting yang harus diamati secara detail dalam suatu kajian kondisi jalan tambang karena akan mempengaruhi kinerja alat angkut yang melaluinya. Menurut Kepmen ESDM No. 1827 K/30/MEM/2018, grade jalan tambang/ produksi dibuat tidak boleh lebih dari 12\%. Namun, berdasarkan SOP PT PAMA, kemiringan jalan angkut tambang tidak boleh lebih dari 8\%. Penulis memilih grade $8 \%$ atas pertimbangan bahwa akan ada penyimpangan dalam penerapan pembuatan ramp di lapangan yang dapat menyebabkan grade ramp aktual melebihi peraturan yang telah ditetapkan. Oleh karena itu, penulis memilih nilai grade ramp maksimum $8 \%$ yang akan digunakan dalam proses pembuatan rancangan jalan angkut tambang.

\section{Penjadwalan Produksi 3 Month Rolling Plan (3 MRP) Bulan April - Juni 2019}

Pada tahap pembuatan rancangan sequence penambangan, faktor waktu telah mulai dimasukkan sebagai pertimbangan membuat urutan penambangan. Hasilnya adalah penjadwalan produksi setiap bulan berdasarkan rancangan penambangan tahunan yang telah dihasilkan.

Dalam penelitian ini, pembuatan rancangan penambangan dilakukan setiap bulan berdasarkan penjadwalan produksi untuk bulan April - Juni 2019 di Area Mitsubishi. Perancangan mengikuti target produksi serta stripping ratio yang direncanakan pada area penambangan tersebut. Penjadwalan produksi 3 Month Rolling Plan (3 MRP) Bulan April - Juni 2019 di Area Mitsubishi, dapat dilihat pada Tabel 2.

\section{Tabel 2 Target Produksi Bulan April - Juni tahun 2019 di Area Mitsubishi}

\begin{tabular}{llll}
\hline \multicolumn{1}{c}{ Bulan } & Overburden (BCM) & \multicolumn{1}{c}{ Batubara (Ton) } & \multicolumn{1}{c}{ SR } \\
\hline April & 803.469 & 78.006 & 13,92 \\
Mei & 937.792 & 166.828 & 7,6 \\
Juni & 635.174 & 129.125 & 6,65 \\
\hline
\end{tabular}

\section{Rancangan Sequence Penambangan Bulan April 2019}

Berdasarkan kebutuhan volume rancangan penambangan di Area Mitsubishi pada bulan April yang terdapat pada Tabel 2, maka perlu dilakukan perancangan penambangan dengan kapasitas volume material paling sedikit overburden sebesar 803.469 BCM dan batubara sebesar 78.006 Ton dengan SR 13,92. Hasil rancangan penambangan di Area Mitsubishi dari rancangan pada Bulan April 2019 dapat dilihat pada Gambar 8. 
Perancangan Sequence Penambangan Batubara di Pit Tutupan Selatan Area Mitsubishi, PT Pamapersada Nusantara Jobsite PT Adaro Indonesia, Kalimantan Selatan

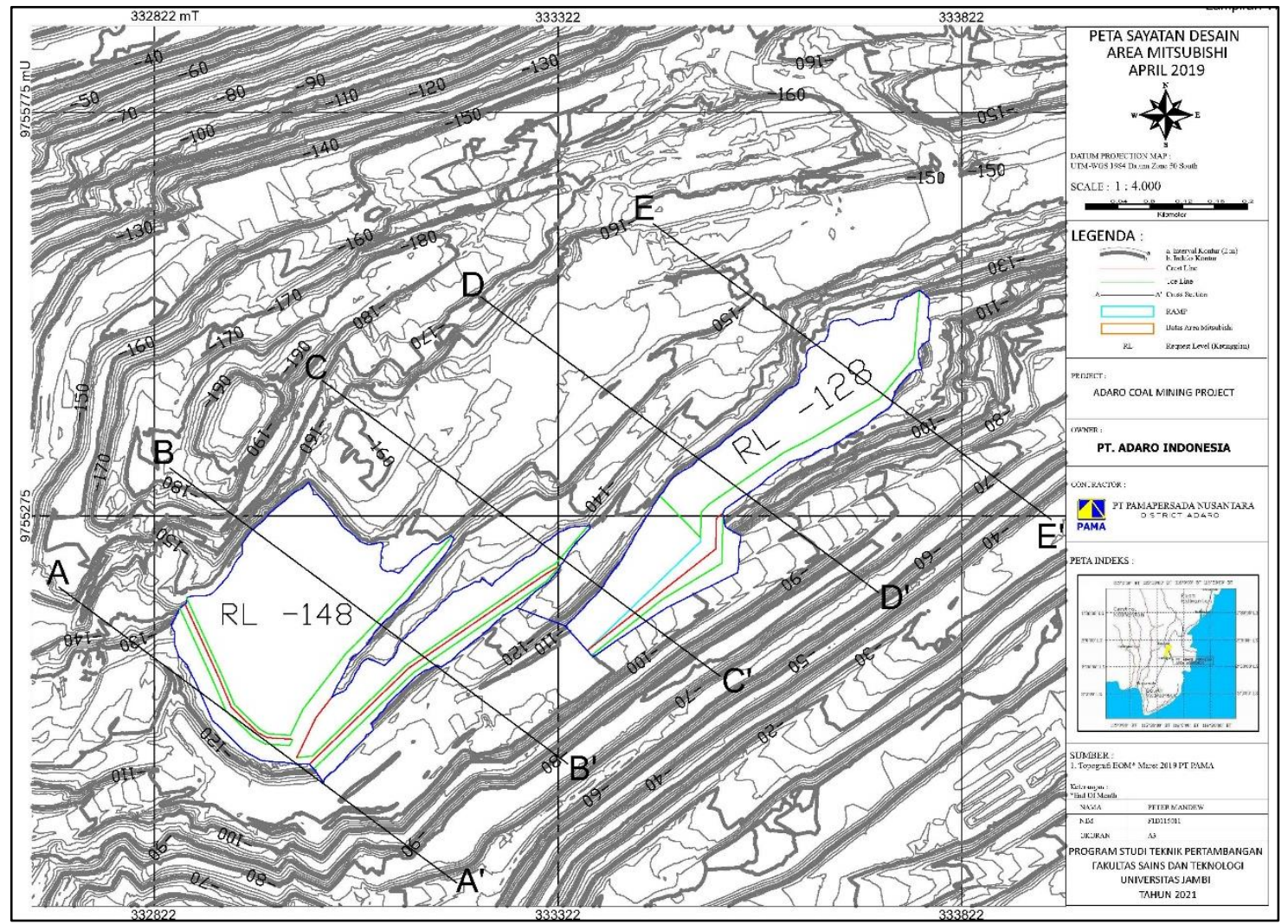

Gambar 8. Rancangan Penambangan di Area Mitsubishi Bulan April 2019

Pada hasil rancangan bulan April di Area Mitsubishi diperoleh rancangan dengan volume overburden sebesar 880.324 BCM dan batubara sebesar 183.949 ton dengan SR 6,47. Secara ringkas, hasil rancangan sequence penambangan Bulan April 2019 dapat dilihat pada Tabel 3 .

Tabel 3 Hasil Rancangan Sequence Penambangan Bulan April 2019

\begin{tabular}{|c|c|c|}
\hline No. & Deskripsi & Keterangan \\
\hline 1. & Luas bukaan penambangan & $13,2 \mathrm{Ha}$ \\
\hline 2. & Rencana penurunan elevasi (RL) & Area Barat $=\mathrm{RL}-148 \mathrm{mdpl}$ \\
\hline & & Area Timur $=\mathrm{RL}-128 \mathrm{mdpl}$ \\
\hline 3. & Jalan angkut tambang (Ramp) & $\begin{array}{l}\text { Penghubung Area di sebelah timur } \\
\text { pada elevasi }-112 \text { mdpl terhadap } \\
\text { elevasi }-128 \text { mdpl dengan jarak } \\
200 \text { meter }\end{array}$ \\
\hline 4. & Kemiringan jalan (Grade) & $4,57 \%$ \\
\hline 5. & Volume rancangan & $\begin{array}{l}\text { Overburden }=880.324 \mathrm{BCM} \\
\text { Batubara }=183.949 \text { ton }\end{array}$ \\
\hline 6. & Stripping Ratio (SR) rancangan & 6,47 \\
\hline
\end{tabular}

\section{Rancangan Sequence Penambangan Bulan Mei 2019}

Berdasarkan kebutuhan volume rancangan penambangan di Area Mitsubishi pada bulan Mei yang terdapat pada Tabel 2, maka perlu dilakukan perancangan penambangan dengan kapasitas volume material paling sedikit overburden sebesar 937.792 BCM dan batubara sebesar 166.828 Ton dengan SR 7,41. Hasil rancangan 
penambangan di Area Mitsubishi dari rancangan pada Bulan Mei 2019 dapat dilihat pada Gambar 9.

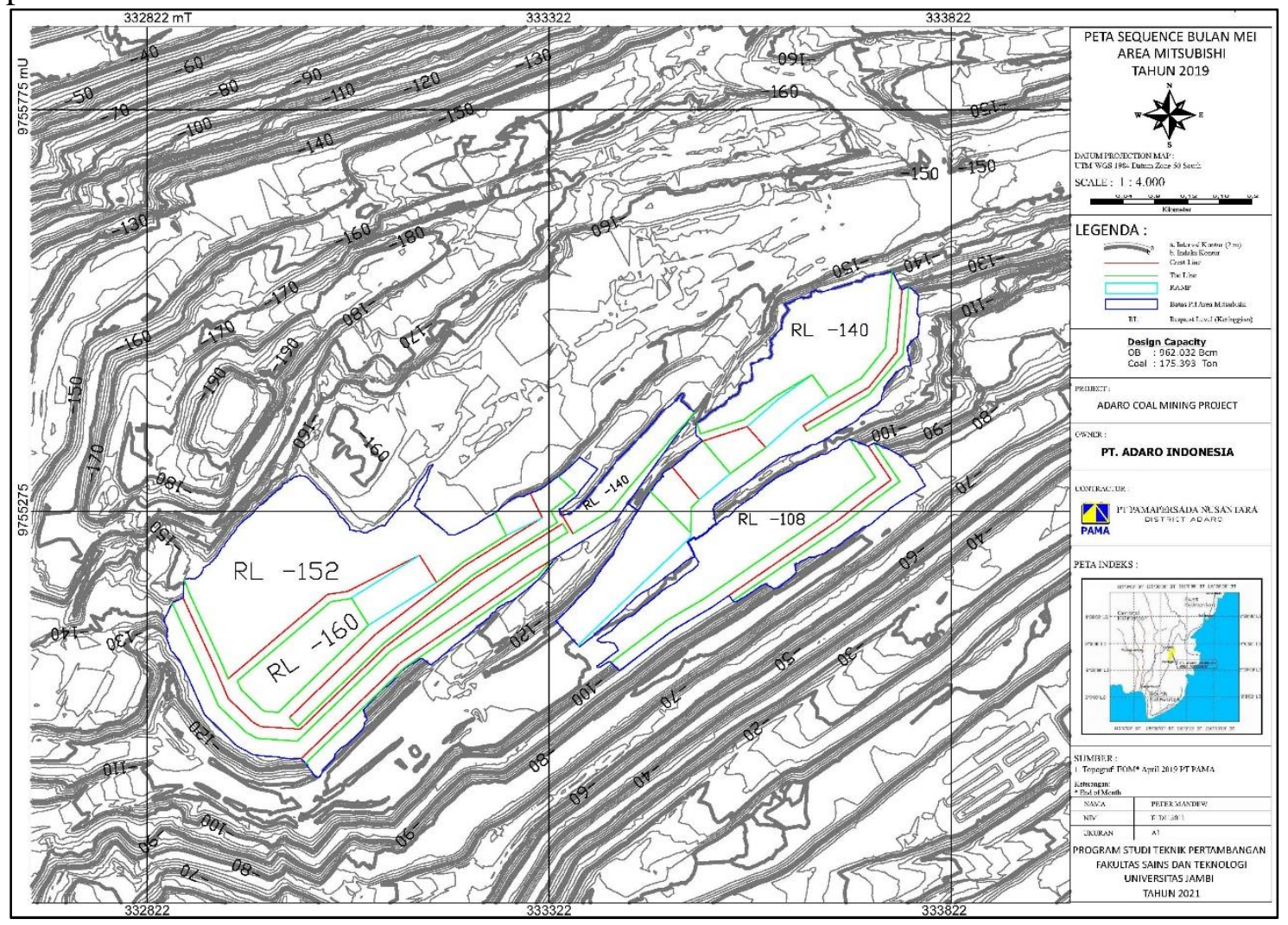

Gambar 9. Rancangan Penambangan di Area Mitsubishi Bulan Mei 2019

Pada hasil rancangan bulan Mei di Area Mitsubishi diperoleh rancangan dengan volume overburden sebesar 962.032 BCM dan batubara sebesar 175.393 ton dengan SR 7,41. Secara ringkas, hasil rancangan sequence penambangan Bulan Mei 2019 dapat dilihat pada Tabel 4.

Tabel 4 Hasil Rancangan Sequence Penambangan Bulan Mei 2019

\begin{tabular}{cll}
\hline No. & \multicolumn{1}{c}{ Deskripsi } & \multicolumn{1}{c}{ Keterangan } \\
\hline 1. & Luas bukaan penambangan & $20,76 \mathrm{Ha}$ \\
2. & Rencana penurunan elevasi (RL) & Area Barat $=\mathrm{RL}-152 \mathrm{mdpl}$ dan \\
& & $\mathrm{RL}-160 \mathrm{mdpl}$ \\
& Area Tengah $=\mathrm{RL}-140 \mathrm{mdpl}$ \\
& Area Tenggara $=\mathrm{RL}-108 \mathrm{mdpl}$ \\
& Area Timur $=\mathrm{RL}-140 \mathrm{mdpl}$ \\
& 1. Penghubung Area Barat pada \\
& Jalan angkut tambang (Ramp) & elevasi -148 mdpl terhadap elevasi \\
& -152 mdpl dengan jarak 50 meter \\
& dan elevasi -152 mdpl terhadap \\
& elevasi -160 mdpl dengan jarak \\
& 100 meter \\
& 2. Penghubung Area Timur pada \\
& elevasi -112 mdpl terhadap elevasi \\
& -128 mdpl dengan jarak 200 meter, \\
& pada elevasi -128 mdpl terhadap
\end{tabular}


Perancangan Sequence Penambangan Batubara di Pit Tutupan Selatan Area Mitsubishi, PT Pamapersada Nusantara Jobsite PT Adaro Indonesia, Kalimantan Selatan
4. Kemiringan jalan (Grade)
5. Volume rancangan
6. Stripping Ratio (SR) rancangan
1. $4,59 \%$ dan $4,57 \%$
2. $5,06 \%, 4,56 \%$, dan $4,57 \%$
Overburden $=962.032 \mathrm{BCM}$
Batubara $=175.393$ ton
7,41

elevasi -132 mdpl dengan jarak 50 meter, dan pada elevasi $-132 \mathrm{mdpl}$ terhadap elevasi -140 mdpl dengan jarak 100 meter

\section{Rancangan Sequence Penambangan Bulan Juni 2019}

Berdasarkan kebutuhan volume rancangan penambangan di Area Mitsubishi pada bulan Juni yang terdapat pada Tabel 2, maka perlu dilakukan perancangan penambangan dengan kapasitas volume material paling sedikit overburden sebesar 635.174 BCM dan batubara sebesar 129.125 Ton dengan SR 6,65. Hasil rancangan penambangan di Area Mitsubishi dari rancangan pada Bulan Juni 2019 dapat dilihat pada Gambar 10.

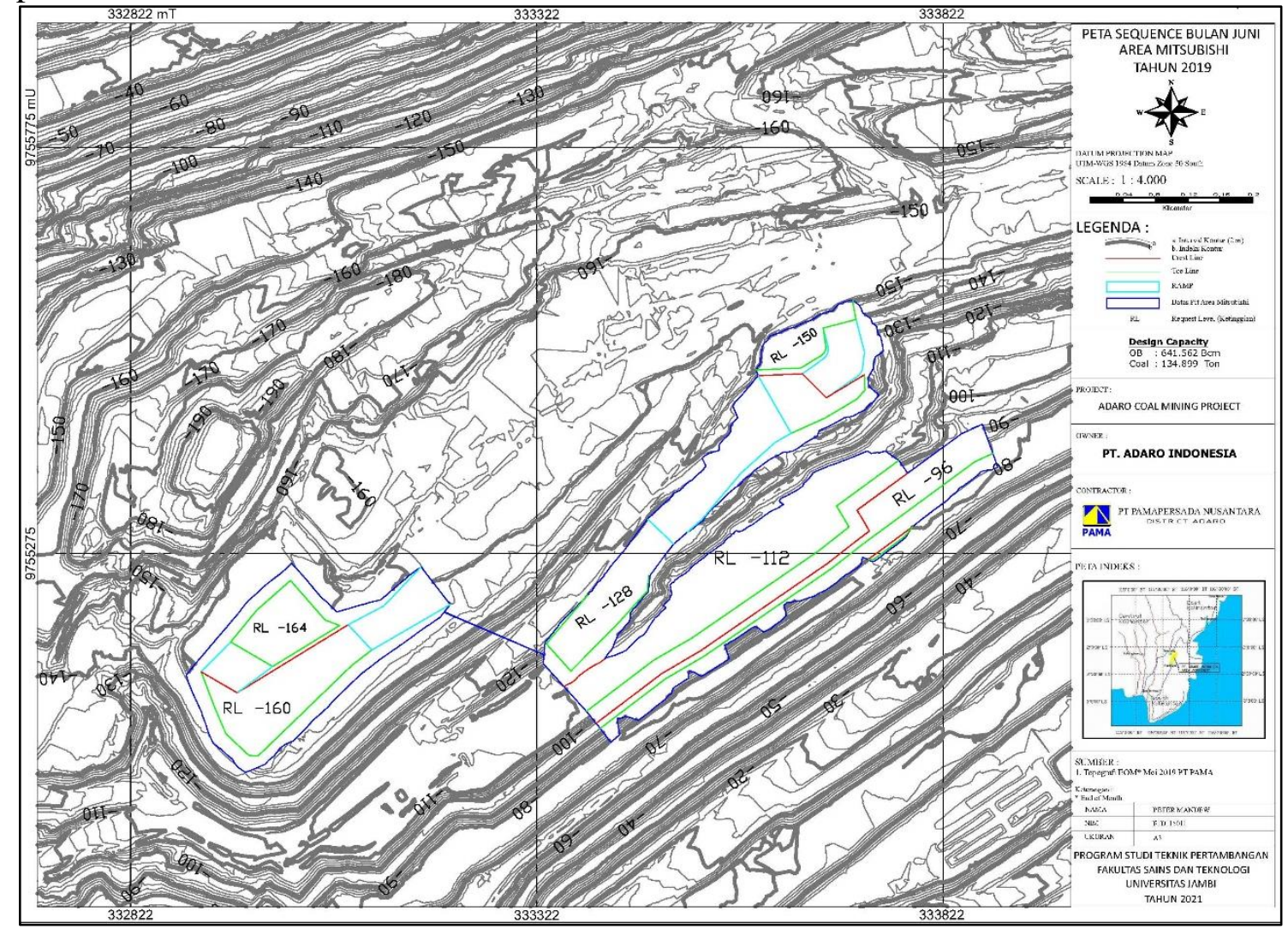

Gambar 10. Rancangan Penambangan di Area Mitsubishi Bulan Mei 2019

Pada hasil rancangan bulan Juni di Area Mitsubishi diperoleh rancangan dengan volume overburden sebesar 641.562 BCM dan batubara sebesar 134.899 ton dengan SR 6,43. Secara ringkas, hasil rancangan sequence penambangan Bulan Juni 2019 dapat dilihat pada Tabel 5.

Tabel 5 Hasil Rancangan Sequence Penambangan Bulan Juni 2019

\begin{tabular}{ccc}
\hline No. & Deskripsi & Keterangan \\
\hline 1. & Luas bukaan penambangan & $14 \mathrm{Ha}$
\end{tabular}


Peter Mandew, Heru Juanda Putra, Ryan Habrianto, dan Zico Hardianto

2. Rencana penurunan elevasi (RL)

Area Barat $=\mathrm{RL}-160 \mathrm{mdpl}$ dan

RL -164 mdpl

Area Tengah $=\mathrm{RL}-128 \mathrm{mdpl}$

Area Timur $=\mathrm{RL}-150 \mathrm{mdpl}$

Area Tenggara $=$ RL -96 mdpl dan

RL -112 mdpl

3. Jalan angkut tambang (Ramp) 1. Penghubung Area Barat pada elevasi -152 mdpl terhadap elevasi -160 mdpl dengan jarak 112 meter dan elevasi -160 mdpl terhadap elevasi -164 mdpl dengan jarak 51,8 meter

2. Penghubung Area Timur pada elevasi -128 mdpl terhadap elevasi -144 mdpl dengan jarak 200 meter dan pada elevasi $-144 \mathrm{mdpl}$ terhadap elevasi -150 mdpl dengan jarak 120 meter

4. Kemiringan jalan (Grade) 1. $4,10 \%$ dan $4,43 \%$

2. $4,60 \%$ dan $3,18 \%$

5. Volume rancangan

Overburden $=641.562 \mathrm{BCM}$

Batubara $=134.899$ ton

6. Stripping Ratio (SR) rancangan 6,43

\section{Kesimpulan}

Rancangan sequence di Area Mitsubishi didesain dengan parameter geometri lereng sequence penambangan dirancang dengan lebar bench 10 meter, tinggi bench 16 meter, dan kemiringan bench $30^{\circ}$. Selanjutnya lebar working bench minimum adalah 30 meter dan lebar jalan angkut untuk jalan lurus dua jalur adalah $23 \mathrm{~m}$ dengan grade maksimum sebesar $8 \%$. Hasil kapasitas rancangan sequence penambangan untuk bulan April mempunyai kapasitas overburden sebesar 880.324 BCM dan batubara sebesar 183.949 ton dengan SR 6,47; bulan Mei mempunyai kapasitas overburden sebesar 962.032 BCM dan batubara sebesar 175.393 ton dengan SR 7,41; bulan Juni mempunyai kapasitas overburden sebesar 641.562 BCM dan batubara sebesar 134.899 ton dengan SR 6,43. 
Perancangan Sequence Penambangan Batubara di Pit Tutupan Selatan Area Mitsubishi, PT Pamapersada Nusantara Jobsite PT Adaro Indonesia, Kalimantan Selatan

\section{Bibliografi}

Amperadi, Tri Budi. (2015). Rancangan teknis desain push back penambangan batubara pada pit 1a di pt. Nata energi resourses job site pt. Atha marth naha kramo, kabupaten malinau, propinsi kalimantan utara. Jurnal Geologi Pertambangan (JGP), 1(17), 15-28.

Arteaga Munoz, Felipe. (2014). The mining rate in open pit mine planning.

Aryanda, Dadang, Ramli, Muhammad, \& Djamaluddin, H. (2016). Perancangan Sequence Penambangan Batubara Untuk Memenuhi Target Produksi Bulanan. Jurnal Penelitian Geosains, 10(2).

Bargawa, W. S. (2018). Perencanaan Tambang. Yogyakarta: Kilau Book.

Febrian, Dimas Tidar. (2014). Rancangan Desain Pit Batubara Di PT Cakra Persada Mandiri Mining (PT CPMM) Desa Panaan, Kec. Bintan Ara Kabupaten Barito Utara Provinsi Kalimantan Tengah.

Geost, F. (2016). Geologi Regional Cekungan Barito ; Fisiografi, Stratigrafi, Struktur, dan Sejarah Geologinya. Retrieved from https://www.geologinesia.com/2016/03/geologi-regional-cekungan-barito.html. Diakses 1 Februari 2019 website: https://www.geologinesia.com/2016/03/geologiregional-cekungan-barito.html. Diakses 1 Februari 2019

Gusmaningsih, Kiki, Murad, Murad, \& Yulhendra, Dedi. (2018). Desain Pit Tambang Air Laya Barat Untuk Memenuhi Target Produksi Tahun 2018 PT. Bukit Asam (Persero) Tbk Sumatera Selatan. Bina Tambang, 3(3), 963-973.

Hustrulid, William A., Kuchta, Mark, \& Martin, Randall K. (2013). Open pit mine planning and design, two volume set \& CD-ROM pack. CRC Press.

Ikhwal, Rahmad Febrian, \& Murad, Murad. (2019). Perhitungan Sumberdaya Batubara dan Permodelan Pit 2 Pada PT. Andhika Yoga Pratama (AYP), Kecamatan Pauh, Kabupaten Sarolangun, Jambi. Bina Tambang, 4(1), 297-306.

Kajian, Tim Penyusun. (2016). Laporan Akhir Kajian Ketercapaian Target DMO Batubara Sebesar 60\% Produksi Nasional Pada Tahun 2019. jakarta: Direktorat Sumber Daya Energi, Mineral dan Pertambangan BAPPENAS.

Nusantara, PT Pamapersada. (2017). Standar Operasional Prosedur. Retrieved from $\% 60$ 
Peter Mandew, Heru Juanda Putra, Ryan Habrianto, dan Zico Hardianto

Prinandi, Arik Rizkia. (2015). Perancangan (Design) Pit EF Pada Penambangan Batubara Di PT Milagro Indonesia Mining Desa Sungai Merdeka, Kecamatan Samboja Kabupaten Kutai Kartanegara Provinsi Kalimantan Timur.

Purwaningsih, Diyah Ayu. (2017). RANCANGAN TEKNIS DESAIN PUSH BACK PADA PENAMBANGAN BATUBARA PIT 10 DAN PIT 13 PT. KAYAN PUTRA UTAMA COAL KABUPATEN KUTAI KARTANEGARA KALIMANTAN TIMUR. Jurnal Geologi Pertambangan (JGP), 1(21), 13-15.

PUTERA, AWANG SEPTIAN, Toha, M. Taufik, \& Bochori, Bochori. (2020). PERENCANAAN TEKNIS SEKUEN PENAMBANGAN BATUBARA DAN DISPOSAL OVERBUDEN PT BUDI GEMA GEMPITA, LAHAT, SUMATERA SELATAN. Sriwijaya University.

Wibowo, Prasetyo, Usman, Dudi Nasrudin, \& Maryanto, Mayanto. (2019). Perencanaan dan Perancangan Penambangan Pasir di CV Cahaya Press Subur di Desa Cibogo, Kecamatan Cibogo, Kabupaten Subang, Jawa Barat.

Yusha, A. S. (2019). Perencanaan Sekuen Penambangan Batubara Tahun 2019 Pada Pit W4 PT Saptaindra Sejati (SIS) Jobsite PT Adaro Indonesia Tabalong Provinsi Kalimantan Selatan. Universitas Lambung Mangkurat. 